\title{
Evaluation of Sublethal Dichlorvos Poisoning on Blood Cells and Enzymes of Clarias anquillaris
}

\author{
Iniobong Reuben Inyang ${ }^{1}$, Ifiemi Joseph Francis ${ }^{1}$, Sylvester Chibueze Izah $^{2 *}$ \\ ${ }^{1}$ Environmental Toxicology Research Unit, Department of Biological Sciences, Niger Delta University, \\ Wilberforce Island, Bayelsa State, Nigeria \\ ${ }^{2}$ Department of Biological Sciences, Bayelsa Medical University, Yenagoa, Bayelsa State, Nigeria
}

*Corresponding Author: Sylvester Chibueze Izah, Department of Biological Sciences, Bayelsa Medical University, Yenagoa, Bayelsa State, Nigeria.

\begin{abstract}
This present study was carried out to unveil the effect of dichlorvos (a well-known organophosphate insecticide) on adult Clarias anquillaris (Linneaus, 1758) blood cells and enzymes. Twenty-six probe organism (mean weight, 1020.59 and mean length, $28.020 .2 \mathrm{~cm}$ ) were acclimatized to laboratory condition for 10 days and then exposed to varying sublethal concentration of dichlorvos $\left(0.20,0.40\right.$, and $\left.0.60 \mathrm{mgl}^{-1}\right)$ in a semi static bioassay for 20 days. Blood cells viz: white blood cell (WBC), Red blood cell (RBC), haemoglobin (Hb), lymphocytes (Lyp), pack cell volume (PCV), eosinophils (Eos) and Monocyte (mono) were determined in the blood sample while Phosphatases (acidic phosphatase, ACP and alkaline phosphatase, ALP) were determined in the liver. Blood cells (WBC, RBC, Hb, PCV, Mono) values were not statistically significant, however values unveiled a slight demarcation from the control. Mean cell volume (MCV) and Mean cell haemoglobin concentration (MCHC) values also showed a slight demarcation from the control. Phosphatases (ACP and $A L P)$ values were statistically significant. ALP values elevate in a dose dependent pattern while ACP values decreases down the experimental group (not in a dose dependent pattern). It is concluded that dichlorvos could be toxic at high concentration significantly on the enzymes. Enzymes tested could be very useful biomarker of sublethal effect of dichlorvos than blood cells. Further studies are required to elucidate the potential environmental risk of dichlorvos.
\end{abstract}

Keywords: Dichlorvos, blood cells, Clarias anquillaris, enzymes.

\section{INTRODUCTION}

Pesticide research over the years has affirmed the toxic potentialities of these chemicals on organisms. Pesticides by their nature are toxic compounds and as such besides controlling pests, they also have potentialities of affecting the life and environment adversely (Ahmed and Gautam, 2014). Contamination of water by pesticides, either directly or indirectly, can lead to fish kills, reduced fish productivity or elevated concentrations of undesirable chemicals in edible fish tissue which can affect the health of humans consuming these fish (Velisek et al., 2011). Heavy contamination of water by pesticides in turns leads to oxygen depletion, poisoning and resultant mass mortality of fishes has been reported (Atamnalp et al., 2001). Reproductive failures attributed to pesticides have been reported by Bostveld et al. (1995). Additionally, pesticides effect on African catfish Clarias gariepinus enzymes, haematology and metabolites have also been reported by Inyang (2008), Izah and Richard (2020).

Because of the environmental longevity and toxic effects organochlorine pesticides, the agriculture industry has increasingly relied upon organophosphate pesticides (Cowman and Mozanti, 2000; Amrolabi et al., 2010). According to Britt (2000), organophosphate pesticides do not bioaccumulate in tissues and organism or accumulate in the environment as do organochlorine. Organophosphate insecticides include chloropyrifos, diazinon, parathion and dichlorvos. In Nigeria, dichlorvos is one of the most prevalent insecticides used commonly by farmers and non-farmers for annihilation of insects and prevention of stored grain from insect damage and control of flies in mushroom house (Inyang et al., 2013). Dichlorvos (2,2 dichlorovinyl dimethyl phosphate), also known as DDVP or snipper is carelessly handed in Nigeria and it has become a suicide tool to youths.

The organophosphate insecticides have two distinctive features; they are generally much more toxic to vertebrates than other classes of insecticides and most are chemically unstable or non-persistent. 
Organophosphate affect many vital organs, chronic toxicity with organophosphorus pesticides may cause extreme injury in liver cells (Kumar, 2010). According to Durak (2009), Vani (2012), haematological parameters such as haemoglobin, leucocyte count and coagulation of blood have been considered as bioindicator of toxicants following chronic exposure to toxicants such as malathion and cypermethrin. Dichlorvos and other organophosphate insecticides are known to alter the haematological indices of fish. Gunde and Yerli (2012) and Koul et al. (2000) have reported effect of dichlorvos on guppy (Poecilia reticulate and Cyprinus Carpio) and Channa gachua (HAM) respectively. According to Dick and Dixon (1985), findings on the effect of Copper indicated decreased erythrocytes and leucocytes, they concluded that the effect was due to reduction in blood production or annihilation by the toxicant which will result in anaemia and leucopenia.

Many studies have shown that biochemical changes occurred in fishes that were exposed to environmental contaminants (Hassel, 1990, Luskova et al., 2002). Biochemical characteristics of blood are among the important indices of the status of internal environment of fish (Edsall, 1999). Organophosphates pesticide are known to inhibit several enzymes eg acetycholinesterase. Thangnipon et al (1995) studied the neurotoxic effects of monoclotophos (Organophosphate insecticide) on the brain of Nile Tilapia (Oreochromis niloticus) in a static bioassay under laboratory conditions. They unveiled acute decrease in brain acetylcholinesterase with progressive increase in concentration of the toxicant.

A biomarker may be any measurable biochemical, cellular, physiological or behavioural change in an organism or population that indicate exposure to chemical pollutant (Depledge, 1994). Biochemical indicators of environmental contamination have potential use as sensitive and early warning indicators of long term detrimental effects and several of these ecotoxicological studies have implied that haematological changes such as increased levels of plasma enzymes occurred in some vertebrates after exposure to pesticides (Abdo et al., 1983; Abau-Donia 1990; Lapadula et al., 1990). Hence, this study evaluates the sublethal dichlorvos poisoning on blood cells and enzymes of Clarias anquillaris.

\section{Materials ANd Methods}

\subsection{Experimental Stock}

Fish sample (adult Clarias anquillaris (Linnaeus 1758) for this present study were obtained from a private fish farm in Wilberforce Island, Amassoma, Bayelsa State, were the assay were conducted from October to November, 2019. Twenty six adult Clarias anquillaris (Linnaeus 1758), mean weight $102 \pm 0.5 \mathrm{~g}$ and mean length $28.02 \pm 0.2 \mathrm{~cm}$ were acclimatized individually in a circular aquaria for 10 days during which they were fed once a day $(10.00-11.00 \mathrm{hr})$ with $35 \%$ crude protein at $10 \%$ biomass.

\subsection{General Bioassay Technique}

Sublethal concentrations of the toxicant (dichlorvos) for this assay $\left(0.20,0.40,0.60 \mathrm{mgl}^{-1}\right)$ were determined based on the range finding test. These were prepared by transferring $0.010 \mathrm{mls}, 0.020 \mathrm{mls}$ and $0.030 \mathrm{mls}$ respectively from the original concentration of the toxicant and making it up to $30 \mathrm{~L}$ with borehole water in the circular aquaria. 30L of the diluent (borehole water, devoid of impurities) was used as control. There were four treatment levels with four replicates. The exposure period lasted for 20 days during which the exposure media were renewed every 48 hours. The physiological characterization of the water used for this bioassay was carried out using standard method of APHA (1998) and the following values were obtained: temperature $25^{\circ} \mathrm{C}-26^{\circ} \mathrm{C}, \mathrm{pH} 6.18-6.33$, alkalinity $15.37-$ $16.98 \mathrm{mgl}^{-1}$, turbidity $0.28-0.43 \mathrm{NTU}$, dissolved oxygen $5.40-6.35 \mathrm{mgl}^{-1}$ and conductivity $70.20-101.1 \mu \mathrm{S} / \mathrm{cm}$.

At the end of the designed period (20 days), Blood samples were collected for haematological analysis. Analysis was based on the method designed by Elelaimy et al. (2012). Mean cell haemoglobin (MCH), mean cell volume (MCV) and mean cell haemoglobin concentration (MCHC) were calculated respectively using standard formular described by Dacie and Lewis (1991). 0.5g of Liver tissue was macerated with pestle and mortar. Physiological saline was used for preservation. Samples were centrifuged at the rate of 300rpm for 15 minutes. The supernatants were then removed and stored in plain bottles at $-20^{\circ} \mathrm{c}$ for analysis. Activities of phosphatases (acid phosphatase and Alkaline phosphatase) were analyzed using Kind and King (1954) and Andersch and Szcypinski (1947) methods respectively

\subsection{Data Analysis}

The data were expressed as mean \pm standard deviation. One-way analysis of variance (ANOVA) were used to show significant variations at $\mathrm{p}=0.05$. Where differences exist, Duncan multiple range test (DMRT) were used to test for pair wise significant differences between treatments 


\section{RESULTS AND DISCUSSION}

\subsection{Enzymes}

Table 1 shows activities of enzymes in the liver of Clarias anquillaris exposed to dichlorvos for 20 days. Activities of ALP increase down the experimental group compared to control. Values recorded apparently indicated a dose dependent pattern. Acid phosphatase values decrease down the experimental group unlike the ALP, but not in dose dependent pattern. The lowest value was recorded at $0.4 \mathrm{mgl}^{-1}$ $(4.25 \pm 0.03 \mu / \mathrm{l})$ compared to control that had $30.34 \pm 0.91 \mu / 1$.

Alterations in these enzymes activities of fish resulting from toxicant or contaminant effects in various organs of fish have been reported (Belgum, 2004; Inyang, 2008; Inyang et al., 2014; Das and Murherjee, 2000). Such biochemical changes in fish are aimed at maintaining equilibrium in the presence of these toxicants, which are known to disrupt physiological and biochemical processes (Wedemger and Micleay, 1981). Decreased levels of ALP activity in this research depicts that liver tissue of the exposed fish may have been impaired by dichlorvos. This present result is not in consonance with the work of Ovuru and Mgbere (2000) and Sastry and Sherma (1980). According the authors, ALP exhibited a remarkable decrease in the experimental group as the concentration of the toxicant increases when they exposed Oryclotagus niloticus to crude oil and Channa punctatus to dichlorvos respectively. The present results in agreement with Abdel-Ghany et al. (2016), Kalender et al. (2010). The authors reported overt increase in concentration of ALP as the toxicant concentration increases. According to Edquist et al. (1992), ALP activity is a reflection of changes in endoplasmic reticulum mass, it is also known to occur in the cell membrane and may be involved in metabolic transport. Kaur and Dhanju (2004) reported a significant increase in the activities of AST, ALT and ALP in the liver of albino rats exposed to monoclotophos, methyl parathion and dimethoate, given orally for 90 days, and inferred that such increase is an indicator of cellular toxicity of these organophosphate causing a release of the enzymes into the blood.

Acid phosphatase (ACP) concentration in the experimental group were significant. A clear decrease in values characterized the experimental group. Values decreases down the experimental group (not in a dose dependent), Table 1. Decrease in values was also recorded by Aly and El-Gendy (2014) and Jawale (2016). The decrease in activity of ACP is caused by the toxicant. According to Jawale (2016), acid phosphatase is hydrolytic lysosome enzyme and is released by the lysosome for hydrolysis of foreign material. Harper (1991) added that ACP also play a role in certain detoxification function. The decrease in ACP may be related either to leakage of the enzyme into extracellular compartments or tissue damage (Ambali et al., 2007). Rashman et al. (2000) suggested that the decrease in the activities of ALP and ACP in different tissues might be due to the increased permeability of plasma membrane or cellular necrosis, showing the stress condition of the probe organism. The decrease in values also depicts inhibition by the toxicant.

Table1. Activities of enzymes in the liver of Clarias anquillaris exposed to dichlorvos for 20 days

\begin{tabular}{|c|c|c|}
\hline $\begin{array}{c}\text { Conc. Of dichlorvos } \\
\left(\mathrm{mgl}^{-1}\right)\end{array}$ & $\begin{array}{c}\text { ALP } \\
(\mu / \mathrm{l})\end{array}$ & $\begin{array}{c}\text { ACP } \\
(\mu / 1)\end{array}$ \\
\hline 0.00 & $303.50 \pm 4.60^{\mathrm{c}}$ & $30.34 \pm 0.91^{\mathrm{a}}$ \\
\hline 0.20 & $348.50 \pm 10.20^{\mathrm{b}}$ & $13.96 \pm 0.03^{\mathrm{b}}$ \\
\hline 0.40 & $368.50 \pm 7.21^{\mathrm{b}}$ & $4.25 \pm 0.03^{\mathrm{c}}$ \\
\hline 0.60 & $421.00 \pm 6.72^{\mathrm{a}}$ & $7.28 \pm 0.01^{\mathrm{d}}$ \\
\hline
\end{tabular}

Data is expressed as mean \pm standard deviation $(n=3)$. Different superscript within column indicates significant different $(p>0.05)$.

\subsection{Blood Cells}

Table 2 shows the activities of blood cells of Clarias anquillaris exposed to dichlorvos for 20 days.Activities of blood cells unveiled a slight increase in values viz; PCV, WBC, RBC, Hb and lymphocytes, albeit not statistically significant $(\mathrm{P}>0.05)$. Fluctuation and stabilization in values were recorded in neutrophiles and eosinophils while $\mathrm{MCV}, \mathrm{MCH}$ and $\mathrm{MCHC}$ values were not statistically significant. A slight shift in values were recorded in $\mathrm{MCV}, \mathrm{MCH}$ and $\mathrm{MCHC}$.

The evaluation of haematological and biochemical characteristics in fish has become an important means of understanding normal pathological processes and toxicological impacts (Sudova et al., 2008). Haematological and biochemical profiles of blood can provide important information about the internal 
environment of the organism (Manupust, 2000). Leucocytes values increased in the experimental group compared to control. This elevation is in line with the fact that WBC functions against foreign bodies, aided by phagocytosis and antibody production, values will increase as a result of lethalic effect of dichlorvos. The probe organism WBC elevation is caused by dichlorvos effect on the tissue. This elevation is contrary to Inyang (2008) who reported an apparent decrease in values of WBC as the concentration of diazinon increased. Similarly, Ngodegha et al. (1999) opined a decrease in WBC as the concentration of the toxicant (hydrocarbon) increased.

Erythrocytes (red blood cells) value fluctuate within experimental group with a progressive increase at $0.20 \mathrm{mgl}^{-1}$ and $0.60 \mathrm{mg}^{-1}$ A slight diminutive values were recorded at $0.40 \mathrm{mgl}^{-1}$ and $0.60 \mathrm{mgl}^{-1}$. Red blood cell decrease in values has been reported by Svodova et al. (2001) in Cryprinus carpio due to the effect of diazinon. Arees (1978) also reported decreased erythrocytes and haemaglobin count in fresh water fish Channa punctatus after acute exposure to diazinon (a well known organophosphate insecticide). Inyang and Thomas (2016) also reported a decrease in RBC when Clarias gariepinus were exposed to fluazifop-p-butyl. The decrease and increase in values of RBC in this present study is caused by the toxicant. The $\mathrm{RBC}$ is responsible for all transportation and circulation of materials and nutrients in the fish (Inyang and Thomas, 2016). The authors reasoned that decreased in values of RBC suggest an osmotic disturbance and changes in oxygen carrying capacity during fish exposure to toxicant. Additionally, stress and injury in some organs may lead to more production of RBC to cushion the effect of the toxicant (Inyang et al., 2015).

Neutrophiles and Eosinophils are granulolytes also known as polymorplonuclear leucocytes. Values recorded unveil a decrease and increase in experimental group. Neutrophiles values at $0.20 \mathrm{mgl}^{-1}$ and $0.40 \mathrm{mgl}^{-1}$ showed a slight decrease in values compared to control while eosinophils values at $0.40 \mathrm{mgl}^{-}$ ${ }^{1}$ showed a slight elevation while $0.20 \mathrm{mgl}^{-1}$ and $0.60 \mathrm{mgl}^{-1}$ recorded a decrease in values. Fluctuation in values in this study is attributable to dichlorvos effect on these blood cells and the associated organs known for production of these blood cells. Eosinophils are phagocytic cells that inject foreign proteins and immune complexes rather than bacteria (Miller and Harley, 2004). A shift from normal will surely alter the fish physiology.

Haematological aberrations were also recorded in mean cell volume (MCV) and mean cell haemoglobin $(\mathrm{MCH})$ at $0.40 \mathrm{mgl}^{-1}$ while mean cell haemoglobin concentration (MCHC) recorded statistically significant values. A slight increment in value of MCV indicated macrocytic anaemia. This result is akin to the findings of Svodova et al. (2001) when they exposed common carp juveniles were exposed to basudin 600EW diazinon. A rise in values of MCHC indicated macrocytic anaemia.

Table2a. Activities of blood cells of Clarias anquillaris exposed to dichlorvos for 20 days

\begin{tabular}{|c|c|c|c|c|}
\hline $\begin{array}{c}\text { Conc. Of dichlorvos } \\
\left(\mathrm{mgl}^{-1}\right)\end{array}$ & $\begin{array}{c}\text { WBC } \\
\left(\mathrm{mm}^{3} \times 10^{3}\right)\end{array}$ & $\begin{array}{c}\text { RBC } \\
\left(10^{6} \times m m^{-3}\right)\end{array}$ & $\begin{array}{c}\mathrm{Hb} \\
(\mathrm{g} / \mathrm{l})\end{array}$ & $\begin{array}{c}\text { Lymp. } \\
(\%)\end{array}$ \\
\hline 0.00 & $228.30 \pm 9.10^{\mathrm{bc}}$ & $2.35 \pm 000^{\mathrm{c}}$ & $10.20 \pm 0.02^{\mathrm{ab}}$ & $88.50 \pm 0.09^{\mathrm{a}}$ \\
\hline 0.20 & $236.15 \pm 10.10^{\mathrm{b}}$ & $2.45 \pm 0.00^{\mathrm{ab}}$ & $10.20 \pm 0.01^{\mathrm{ab}}$ & $88.50 \pm 0.10^{\mathrm{a}}$ \\
\hline 0.40 & $231.95 \pm 12.10^{\mathrm{b}}$ & $2.30 \pm 0.01^{\mathrm{ab}}$ & $10.25 \pm 0.01^{\mathrm{ab}}$ & $87.00 \pm 0.10^{\mathrm{a}}$ \\
\hline 0.60 & $264.85 \pm 9.30^{\mathrm{a}}$ & $2.70 \pm 0.01^{\mathrm{a}}$ & $11.45 \pm 0.01^{\mathrm{a}}$ & $89.00 \pm 0.20^{\mathrm{a}}$ \\
\hline
\end{tabular}

Data is expressed as mean \pm standard deviation $(n=3)$. Different superscript within column indicates significant different $(p>0.05)$.

Table2b. Activities of blood cells of Clarias anquillaris exposed to dichlorvos for 20 days

\begin{tabular}{|c|c|c|c|c|c|c|c|}
\hline $\begin{array}{c}\text { Conc. Of } \\
\text { dichlorvos } \\
\left(\mathrm{mgl}^{-1}\right)\end{array}$ & $\begin{array}{c}\text { PCV } \\
(\%)\end{array}$ & $\begin{array}{c}\text { Eos } \\
(\%)\end{array}$ & $\begin{array}{c}\text { Mono } \\
(\%)\end{array}$ & $\begin{array}{c}\text { Neu } \\
(\%)\end{array}$ & $\begin{array}{c}\text { MCV } \\
(\mathrm{fl})\end{array}$ & $\begin{array}{c}\text { MCH } \\
(\mathrm{pg})\end{array}$ & $\begin{array}{c}\mathrm{MCHC} \\
(\mathrm{g} / \mathrm{l})\end{array}$ \\
\hline 0.00 & $29.00 \pm 0.02^{\mathrm{ab}}$ & $4.00 \pm 0.01^{\mathrm{ab}}$ & $5.50 \pm 0.01^{\mathrm{ab}}$ & $2.00 \pm 0.00^{\mathrm{a}}$ & $124.55 \pm 0.90^{\mathrm{ab}}$ & $43.25 \pm 0.02^{\mathrm{a}}$ & $290.80 \pm 0.03^{\mathrm{a}}$ \\
\hline 0.20 & $30.50 \pm 0.03^{\mathrm{ab}}$ & $3.00 \pm 0.01^{\mathrm{ab}}$ & $7.50 \pm 0.02^{\mathrm{a}}$ & $1.50 \pm 0.00^{\mathrm{ab}}$ & $124.30 \pm 0.75^{\mathrm{ab}}$ & $41.55 \pm 0.80^{\mathrm{a}}$ & $33.50 \pm 0.05^{\mathrm{b}}$ \\
\hline 0.40 & $30.50 \pm 0.05^{\mathrm{ab}}$ & $5.50 \pm 0.02^{\mathrm{a}}$ & $6.00 \pm 0.02^{\mathrm{ab}}$ & $1.50 \pm 0.01^{\mathrm{ab}}$ & $137.25 \pm 1.20^{\mathrm{a}}$ & $45.00 \pm 0.71^{\mathrm{a}}$ & $32.85 \pm 0.10^{\mathrm{b}}$ \\
\hline 0.60 & $32.50 \pm 0.01^{\mathrm{a}}$ & $3.00 \pm 0.00^{\mathrm{ab}}$ & $5.50 \pm 0.02^{\mathrm{ab}}$ & $2.00 \pm 0.02^{\mathrm{a}}$ & $123.80 \pm 1.30^{\mathrm{ab}}$ & $42.65 \pm 0.63^{\mathrm{a}}$ & $34.90 \pm 0.00^{\mathrm{b}}$ \\
\hline
\end{tabular}

Data is expressed as mean \pm standard deviation $(n=3)$. Different superscript within column indicates significant different $(p>0.05)$.

\section{CONCLUSION}

The result obtained in this study allow us to conclude that the well-known organophosphate insecticide (dichlorvos) promotes aberration in enzymes in the exposed fish (Clarias anquillaris), hence will surely alter the biochemistry of this organism. The blood cells tested did show clearly the effect of this toxicant, 
this may be because of the low concentration of the toxicant used. Application of this xenobiotics in the environment should be done with caution. Further studies are required to elucidate the potential environmental risk of dichlorvos.

\section{REFERENCES}

[1] Abdo, K.M. Timmons, P.R, Graham D.G and Abdu-Donia M.B. 1983. Heinz body production and haematological changes in the hen after administration of a single oral dose of n-butyl-mercaptan and $n$ butyldisulfide. Fundam. Appl. Toxol. 3:67-74.

[2] Abou-Donia, M.B. 1990. Absence of developed neurotoxicity and increased plasma butyrylchlolinesterase activity in trialate treated hen. Fund. Appl. Toxicol. 14.191-198.

[3] Ahmed, S.I and Gautam, R.K. 2014. Effect of Organophosphate pesticide, Nuvan on Serum biochemical parameters of fresh water catfish Heteroprustes fossilis (Bloch). International Journal of Environmental Science, 3(10): 1-6

[4] Aly, N and El-Gendy, K. 2014. Impact of parathion exposure on some biochemical parameters in rabbit as a non-target organism. Alexandria Journal of Medicine, 51 (1): 11-17.

[5] Ambali, S., Akanbi, D., Igbokwe,, N., Sittu, M, Kawu, M. and Ayo J. 2007. Evaluation of sub-chronic chloropyrifos poisoning on haematological and serum biochemical changes in mice and protective effect of vitamin C. Journal of Tropical Science, 32(20): 11-20.

[6] Amrolabi, B.N., Savani, A Mortazavi, M.S and Zolghanein H. 2010. Acute toxicity of Cadmium Chloride on Chanos chanos and their behavior responses, word Journal of Fish and Marine Science, 2:481-486.

[7] Andersch, M.A and Szcypinski, A.J. 1947. A colorimetric method for determination of acid phosphatase from serum. Amer. J. Pathd. 17:571-574.

[8] American Public Health Association (APHA) 1998. Standard Method for examination of water and waste water. 20th edition New York: American Public Health Association.

[9] Arees, M.A. 1978. Haematological abnormalities in fresh water teleost, Channa punctatus (Bloch). Exposed to sublethal and chronic levels of three organophosphate insecticides. International Journal of Ecotoxicology and Environmental Science, 4(1):53-60.

[10] Atamnalp M, Keles, M. S, Halüloúlu, H.U., and Aras M.S. 2001. The effects of cympermethrin (a synthetic pyrethroid) on some biochemical parameters ( $\mathrm{Ca}, \mathrm{P}, \mathrm{Na}, \mathrm{Tp}$ ) of rainbow trout (Oncorhynchus mykiss). Turk J Vet Anim Sci, 26: 1157-1160

[11] Begum, G. 2004. Carbofusion insecticide induced biochemical alteration in lives and muscle tissue of fish. Clarias batrachus (Linn) and recovery response. Aquatic toxicology. 66(1):83-92.

[12] Bostveld, T.A.C, Gradenor, J and Vankampon, M., Murk, A. Evers E.H.G and Van-Denberg, M. 1995. Occurrence and effects of PEBs, PCDDs and PCDFs in hatchings of the common term Csterna hirundo. Chemosphere, 27:419-427.

[13] Brith, J.K, 2000. Principle of toxicology (Environmental and industrial applications. $2^{\text {nd }}$ Ed. A Wiley Interscience Publ. (John Wiley and Sons Inc).

[14] Cowman, D and Mozanti, B. 2000. Ecotoxicology of new generation pesticide to amphibians in C, Bishop, G, Linder, and D Sparling (eds). Ecotoxicology of amphibians. SETAC 233-268.

[15] Dacie, J.V. and S.M. Lewis, 2001. Practical Haematology. In: Lewis, S.M., B.J. Bain, I. Bates, (Eds.), 9th Edn., Churchill Livingstone, Harcourt Publishers Limited, London, pp: 444-451.

[16] Das, B.K and Mukherjee, S.C. 2001. Sublethal effect of quinalphos on selected blood parameters of Labeo rohita (Ham) fingerlings. Asian Fisheries Science, 13:235-238.

[17] Depledge, M.H. 1994. The rational basis for the use of biomarkers as ecotoxicological tools. In: Fossi M.C Leonzio, C editors. Nondestructive biomarkers of vertebrates. Boca Raton. Florida. Lewis.

[18] Dick, PT. and Dixon, D.G. 1985. Changes in circulating blood levels of rainbow trout, Salmo gaidneri Richardson following acute and chronic exposure to copper. Journal of Fish Biology, 26:475-481.

[19] Durak, D., uzum, F.G., Kalender, S. Ogutcu, A Uzuhisar. Cikli and Kaleder, Y. 2009. Malathion-induced oxidative stress in human erythrocytes and the protective effect of vitamin $\mathrm{C}$ and $\mathrm{E}$ in vitro. Environmental toxicology, 24(3): 235-242.

[20] Edquist, L.E, Madej, A and Forsberg, M. 1992. Biochemical blood parameters in pregnant mink lech with PCB and fractions of PCB. Ambio, 21(8) 577-581.

[21] Edsall. C.C. 1999. A blood chemistry profile for lake trout. Journal of Aquatic and Animal Health, 11 (1):81-86

[22] Elelaimy, I.A; Ibrahim, H.M., Abdel-Ghaffar, F.R and Alawthan, Y.S 2012. Evaluation of sub-chronic chloropyrifos poisoning on immunological and biochemical changes in rats and protective effect of eugenol. Journal of Applied Pharmaceutical Science, 02(06):51-61. 
[23] Gunde, G.E., and Yerli, S.V. 2002. The comparative study on the acute toxicity of dichlorvos on guppy (Cyprinus Carpio L, 1758). Journal of Biology and Chemistry. 40(2):165-170.

[24] Harper, H.A. 1991. Harpers review of biochemistry (eds) Murray, R.K., R.K, mayes,, P.A., Granner, D.K and Rodeel, V.W. large medical publication, London England. 400-458.

[25] Hassee, K.A. 1990. The biochemistry and uses of pesticides $2^{\text {nd }}$ edition, Macmillan Press Ltd. London.

[26] Inyang I.R and Thomas, S. 2016. Toxicology of flauzifop-p-butyl on blood cells and metabolites of a common African Catfish (Clarias gariepinus). Nigerian Journal of Agriculture, Food and Environment, 12(2): 128-132.

[27] Inyang I.R, Ogamba, E.N and Frank, N.E. 2013. Biochemical changes and electrolyte stabilization in Clarias gariepinus (juveniles) induced by dichlorovs. International Journal of Biochemistry, 108:244-248.

[28] Inyang I.R., Ogamba, E.N and Inerepamo, O. 2014. Effect of 2,4-Dichlorophenoxyacetic acid on some selected haematological and biochemical parameters in Clarias gariepinus, International Journal of Biochemistry, 108: 368-375.

[29] Inyang I.R., Pughikumo, D.T and Tuesday, T.S. 2015. Haematobiochemical alterations in Clarias lazera induced by deltamethrin. Nigerian Journal of Agriculture, Food and Environment, 11(1): 145-149.

[30] Inyang, I.R. 2008. Haematological and biochemical responses of Clarias gariepinus to diazinon. PhD thesis Rivers State university of science and technology, Port Harcourt, Rivers State.

[31] Izah, S.C., and Richard, G. (2020). Toxicity of Dichlorvos (2, 2- Dichlorovinyl Dimethyl Phosphate) on Fish Life. In: Recent Advances in Biological Research Vol. 6. Pp 70 - 78.

[32] Jawale, C.A. 2016. Consequence of organophosphate dimethoate pesticide on acid phosphatase activity in gills of freshwater fish, Catla catla. Flora and Fauna, 22(1):89-92.

[33] Kalender, S, Uzun F.G., Durak D., Drmir, F and Kalender, S. 2010. Malathion-induced hepatoxicity in rats: the effects of vitamin C and E. Food and Chemical Toxicity, 48(2):633-638.

[34] Kaur, S and Dhanju, C.K. 2004. Enzymatic changes induced by some orgnophosphorus pesticides in female rats. Indian Journal of Experimental Biology, 42(10):1017-1019.

[35] Kind P.R and King, E.G 1954. Estimation of plasma phosphate by determination of hydrolyzed phenol with amino antpyrine, Journal of Clinical Pathology 7:56-63.

[36] Koul, P.C, Mastan, S.A and Pureshi, T.A. 2000. Sublethal effect of dichlorvos (DDVP) on certain biochemical parameters of Channa gachua (HAM). Journal of Herbal Medicine and Toxicity, 1(2): 29-32.

[37] Kumar, S., Farcedullah, M. Sudhakar, B.Y., Venkateswarlu, B and Kumar, E.A. 2010. Current review on organophosphorus poisoning. Achieves of Applied Science Research, 2(4):199-215.

[38] Lapadula, D.M., Johannson, F., and Abou-Donia M.B. 1990. Absence of developed neurotoxicity and increased plasma butyrylchlolinesterase activity in trialate treated hen. Fundam Appl Toxicol. 14:191-198.

[39] Luskova, V., Svobodova, M. and Kolarora, J. 2002. The effects of diazinon on blood biochemistry of carp (Cyprinus carpio) ACTA VET. BRON. 71:117-123

[40] Manupust, J. 2000. Clinical biochemistry (in Zech) karolinum prapue.

[41] Miller, S.A and Harley. J.P. 2004. Zoology (2ed). WC. Brown Publ. USA.

[42] Ngodegha, E.M., Olayimika, F.O., Oruwari, B.M. Ekweozor I.K.E and Wekhe, S.N. 1999. Toxic effects of crude oil on organs and blood cells of West African dwarf goat. Nigerian Veterinary Journal, 20(1).82-91.

[43] Ovuru, S.S and Mgbere, O.O. 2000. Enzyme changes in shrimps (Peneaus notialis) following a brief exposure to weathered bonny light crude oil. Delta Agric. 7(1):62-68.

[44] Rahman, MF. Siddigui. M.K.J, Jamil, C.K. 2000. Inhibition of acetylcholinesterase and different ATPases by a novel phosphorothionate (RPR-II) in rat brain. Ecotoxicol Environ Saf. 47:125-129.

[45] Abdel-Ghany R., Mohammed, E., Anis, S., and Barakat W. 2016. Impact of exposure to fenitrothion on vital organs in rats. Journal of Toxicology, 1:1-18.

[46] Sastry, K.V and Sharma, K. 1980. Diazinon effects on the activities of brain enzymes from Opiocephalus punctatus (Channa). Bulletin of Environmental Contamination and Toxicology 24:326-332.

[47] Sudova, E., Piakova, V., Kroupora, H., Pijacek M., Svobodova, Z. 2008. The effect of praziquantel applied per as on selected haematological and biochemical indices in common carp (Cyrinus carpio L). Fish physiology and Biochemistry. 35(4):599-605.

[48] Svobodova, Z., Macchora, J., Kolarova, J. and Vykusora, B and Plack, V. 2001. The effects of selected negative factors on haematological parameters of common Carp (Cyprinus carpio L) and tench (Tinca tincal). Proc. Sci. papers to the $75^{\text {th }}$ anniversary of foundation of the FIFCA vodnany 95-105.

[49] Thangnipon, W., Luangpborn P and Chinobut, S. 1995. Effects of the organophosphate insecticide (monoclotophos) on acetylcholinesterase activity in the wild tilapia fish (Oreochromis niloticus). Brain Neurochemistry Research, 20(5):587-591 
[50] Vani, T., Saharan, N. and Roy S.D. 2012. Alteration in haematological and biochemical parameters of Catla catla exposed to sublethal concentration of cypermethrin. Fish Physiology and Biochemistry, 38(6):15771584.

[51] Velisek J. Stara, A. and Svobodova, Z. 2011. The Effects of Pyrethroid and Triazine Pesticides on Fish Physiology, Pesticides in the Modern World - Pests Control and Pesticides Exposure and Toxicity Assessment, Margarita Stoytcheva, IntechOpen, DOI: 10.5772/17289.

[52] Wedemeyer, G.A and Mcleay, D.J. 1981. Methods for determining the tolerance of fishes to environmental stressors. Academic press. London.

Citation: Sylvester Chibueze Izah, et.al., " Evaluation of Sublethal Dichlorvos Poisoning on Blood Cells and Enzymes of Clarias anquillaris” International Journal of Research Studies in Biosciences (IJRSB), 8(1), pp 7-13. DOI: http://dx.doi.org/10.20431/2349-0365.0801002

Copyright: (C) 2020 Authors. This is an open-access article distributed under the terms of the Creative Commons Attribution License, which permits unrestricted use, distribution, and reproduction in any medium, provided the original author and source are credited. 